\title{
AN OVERVIEW OF RESEARCH ON PHRYGIAN FROM THE NINETEENTH CENTURY TO THE PRESENT DAY*
}

\begin{abstract}
Contrary to what the title of the paper implies, the author does not limit himself to the presentation of the current state of research on Phrygian, but also provides his own interpretations and evaluations in many places. The very extensive list of references attached will certainly prove to be useful to the reader interested in the subject analysed.
\end{abstract}

On hearing the word 'Phrygian' most people I come across tend to look blank until I remind them of Phrygian stories and personages that seem to be part of our European cultural inheritance, such as King Midas of the golden touch or Alexander the Great cutting the Gordian knot at the Phrygian capital Gordion. Literateurs will of course associate Phrygian with Helen of Troy and her lover Paris Alexander. Classicists will undoubtedly remember Herodotus' story about the twins who were reared without language and one morning clamoured for bekos, the Phrygian word for 'bread.'

It seems to be generally agreed that the Phrygians came to Asia Minor from the Balkans, where they were known by names like Brikes, Brugoi, etc., and they arrived at Gordion (about $100 \mathrm{k} \mathrm{SW}$ of Ankara on the ancient Sangarios river, now called the Sakarya) about the time of the Hittite collapse, i.e. about 1200 BCE. At the height of their power in the $8^{\text {th }}$ century they occupied a sizable chunk of what is now modern Turkey. Their inscriptions are thought to date from the late $8^{\text {th }}$ century BCE and continue down to the fourth century by which time their political power was on the wane. The language of these inscriptions, 50 odd on stone and some 200 on pottery and other small items, is termed Old or Paleo-Phrygian (OPhr.). They are written essentially in an adaptation of a form

\footnotetext{
* A lecture given at a meeting organized by the editorial staff of Studia Etymologica Cracoviensia in the Institute of Oriental Philology, 2 June, 2008.
} 
of the Greek alphabet of c. 700 BCE and are customarily presented in scholarly publications in lower case Roman with some retention of original letter shapes for graphs / graphemes of disputed value.

After the OPhr. period there is a silence of about four centuries until the second century $\mathrm{CE}$ when, for about a century and a half, Phrygian inscriptions reappear, this time exclusively on tombs, and in a much smaller geographic region. They are carved in Greek lettering of the time, and in most cases with an accompanying text in Greek. The Greek is not always very good and there is a sprinkling of Greek words in the Phrygian texts. The language of these inscriptions is called New or Neo- or Late Phrygian (NPhr.). They number about 120. The best understood passage of NPhr. is the opening or protasis of an execration or curse text; a typical form, in the customary representation in lower case Greek letters, is:

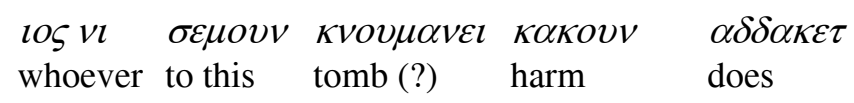

i.e. 'Whoever does harm to this grave/tomb/monument' vel sim.

The minimal conclusion or apodosis - the curse proper - is

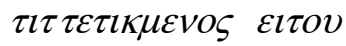

$\begin{array}{ll}\text { (?) cursed (?) may he be / go } & \end{array}$

i.e. 'may he be (or go) cursed (for it?; utterly?).'

There is also a funerary stele dated to the end of the $4^{\text {th }}$ century BCE, but written in the Classical Attic Greek alphabet. This has been repeatedly described as Middle Phrygian by Claude Brixhe (1993: 326f., with a list of characteristic features; 2004: 779, with still no news of an edition).

Apart from these epigraphic texts there are forty or so glosses or remarks on allegedly Phrygian linguistic matters in Greek and Roman authors of antiquity. Apart from doubts about how much of this material is really Phrygian, the readings and even the meanings of much of it is disputed. It really constitutes a secondary source and is best treated as such.

Until the early nineteenth century this secondary material was all that was available to modern European scholarship concerning the Phrygian language. Then a succession of European visitors to Turkey began publishing copies of Phrygian inscriptions. Two Britishers, Walpole (1820) and Leake (1824), published similar copies of two well preserved OPhr. inscriptions ${ }^{1}$ on what is now called the Midas monument, a sculptured rock façade in a natural rock fortress now known as Midas City and located in the western part of the Phrygian realm. Leake, a captain in the British army, is actually credited with discovering this site in 1800 .

\footnotetext{
${ }^{1}$ Numbered M-01a and M-01b in the now standard numbering of OPhr. inscriptions introduced by Brixhe / Lejeune 1984.
} 
Other travellers such as the Frenchman Texier (1839) and the Britisher Steuart (1842) added further OPhr. inscriptions (M-01f, -02, -03, -04) from the Midas monument as well as the three from the nearby Areyastis monument (W-01), so called from the epithet of the mother goddess Kybele / Cybele found in the inscriptions. The first NPhr. items to be really noticed seem to be the four presented by the British geologist Hamilton ${ }^{2}$ (1842. 2: 435- 489, nos. 165, 376, $383,449=$ nos. 7, 5, 12, 25 in the current standard numbering for NPhr. established by Ramsay 1887). Hamilton (1842. 1: 383) also published his drawing of an OPhr. inscription (P-01) found in ancient Pteria far to the east and was uncertain what language it was in.

The first attempt at interpreting any of these texts seems to have been Leake's (1824: 31) reading of three words in one his inscriptions (M-01a), viz. MIDAI ... VANAKTEI EDAE, which he said, if they were Greek, would mean 'divided or cut or inscribed for King Midas ...'. Today we still agree substantially with this interpretation though we read the last word as EDAES and interpret it as 'placed' or 'built' or 'dedicated'; it has also been suggested (by Woudhuizen 1993: 2), but probably not widely accepted, that the dative MIDAI... . VANAKTEI is a dating formula.

The (presumably) Bavarian scholar A.D. Mordtman (1862) is the first interpreter of the texts who gets a mention in Brixhe / Lejeune's standard (1984) corpus of the OPhr. texts. He also added to the small store of then known texts a couple of seemingly fairly impenetrable OPhr. graffiti from the Midas monument (p. 26f.; M-01c and d) and (1861: 191) half of a new inscription from Pteria (P-02). Mordtmann overlooked the other half of the inscription because he thought he was merely producing a corrected copy of the quite different inscription Hamilton had seen in the same locality.

Mordtmann began the process of interpretation by isolating the elements of the NPhr. curse formula from Hamilton's four "Graeco-Phrygian" inscriptions but unfortunately he compared the formula with Greek texts that were not curses but indicated the builder(s) and the occupant(s) of the tombs. By these means and the somewhat dubious help of the segment (si)keneman on the Midas monument Mordtmann did succeed in identifying $\kappa v o v \mu \alpha \nu$ as referring in some way to the tomb. Another positive achievement was Mordtman's recognition of OPhr. matar, materan, etc., 'mother' in the Areyastis inscription and the Midas graffiti. - Incidentally, the alternation tar $\sim$ ter in this paradigm is now part of the evidence for the sound change PIE $* \bar{e}>$ Phrygian $a$, cf. Greek $\mu \eta \dot{\tau} \eta \rho \sim$ $\mu \eta \tau \varepsilon \rho \alpha$. - But Mordtmann was hindered in his interpretations by some bizarre graphological decisions, such as the value /ü/ he assigned to four-bar E, and, I would say, by his desire to fit a meaning to a text at almost any price even though he was painfully aware of the provisional nature of his interpretations.

\footnotetext{
${ }^{2}$ This agrees with Ramsay (1905: 79), though earlier Ramsay (1887: 381) had allowed priority to Pococke's no. 3822e in the Corpus inscriptionum graecarum, 3 (1853), the Phrygian part being there annotated "iis videtur contineri imprecatio fortasse metrica;" in this same volume Hamilton's no. $385=$ CIG 3986b, the set being annotated "ex schedis Seetzenii (21. Oct. 1803.)."
} 
The next noteworthy event is the first useful collection of the glosses by Lagarde (1866: 234ff.) though Mordtmann (1862: 13) gives credit for this to Bötticher.

I have not been able to access Fick's book of 1873 but I understand he was the first to equate B

When, some twenty years after Mordtmann, the British traveller-scholar Ramsay produced his own 15-page corpus of a dozen or so OPhr. ("Archaic Phrygian") inscriptions under the title "early historical relations" etc. (Ramsay 1883: 120-135), he rather stuffily refused to include Mordtmann's graffiti on the grounds that they had been "not worth copying," but his efforts at interpretation were much more restrained. He gave a very detailed commentary on the main Midas inscription (M-01a) in particular identifying edaes as = Greek है $\theta \eta(\tau)-$, but then he tapered off as he moved through his corpus, regarding the texts as consisting largely of theonyms and anthroponyms. This led him to formulate a theory, later taken up by Kretschmer, that the Phrygians had a love of double names like Ates Arkiaevais, Midai Lavaltaei (dative) (M-01a) and Baba Memevais (M-01b and M-02) which made up for their lack of Greek-style compound names. He thought to see Phrygian versions of several Greek names in words we now regard as some sort of official titles, e.g. he equated Lavaltaei, better Lavagtaei, which probably means something like 'leader of the people,' with the name of Odysseus' father Laertes, and similarly Akenanogavos and Proitavos as Achilleus and Proitos, the Argive king, respectively.

Ramsay (1883: 121) was also doubtful about reading $\Lambda$ as lambda and $\Gamma$ with various angles as gamma, suggesting that only $\Gamma$ with a right angle ought to be gamma and $\Gamma$ with an acute angle ought to be lambda, but he did not pursue the matter and thus missed an opportunity to eliminate a graphological perplexity that was to dog Phrygian studies until Lejeune's paper of 1969 (see Lejeune 1969a: 23-25).

Once again anticipating Lejeune (1969a: 40f.), Ramsay (1883: 122) noted that the OPhr. straight-line iota corresponded to a relatively late Greek form while the archaic Greek iota was very similar to the Semitic yod, and that therefore the Phrygians had got their alphabet from the Greeks, and not vice versa. (Lejeune 1969a bolstered this with further arguments; all this was recklessly ignored by Woudhuizen 1993: 3-5).

A few years later Ramsay (1887) produced a workmanlike corpus of 29 NPhr. inscriptions with draughtsman's drawings of the inscriptions plus readings in Greek lower case, information on provenience, copying history, and some discussion. His numbering of the inscriptions is the basis of the standard used today. He gave credit to Schmidt (1869) for making the first real progress with the NPhr. texts in 1869 by showing that some of them contained a curse formula in a language closely akin to Greek; Schmidt had also identified $\varepsilon \imath \tau o v$ at the end of the curse as a $3^{\text {rd }}$ person imperative 'may he be,' but had said nothing about the actual content of the curse. From metrical considerations Ramsay claimed to be able to distinguish several original Greek curses from Greek translations of the Phrygian curses. His inscription no.1 contains such an alleged translation. 
Thus Ramsay identified most of the main elements of the curse much as we do today. His principal oversight was repaired by Fick (1889) who isolated $\mu \alpha v \kappa \alpha$, a common alternative to $\kappa v o v \mu \alpha \nu$ and perhaps meaning 'memorial.' It is perhaps surprising that Ramsay missed this since only a few years before (1884: 254) he had, on the basis of Greek inscriptions, identified the two essential parts of a Phrygian tomb as the altar (B $\Omega M O \Sigma$ ) and the door ( $\Theta Y P A)$, although this identification seems to be largely overlooked nowadays as irrelevant.

Fick's short but important paper confirmed many of Ramsay's results and proposed IE etymologies for some of the Phrygian terms, some which are still taken seriously today, such as $\kappa v o v-\mu \alpha \nu$ to Skt. khan- 'dig,' $\mu \alpha v \kappa \alpha$ to Greek $\mu \nu \eta \hat{\mu} \alpha$. His connection of $\sigma \varepsilon \mu o v v$ to PIE *Kei- 'this' is still controversial and has been taken by some (e.g. Jahukyan 1977: 208) as beginning of the trend of regarding Phrygian as a satem language, though I think this trend must stem in part from statements made by ancient writers to the effect that Phrygian was closely related to Thracian and Armenian, because already in 1883 Ramsay's etymologizing was being influenced by his belief that PIE * ga- would yield Phrygian $z a$ - unless it was the labialized sound reflected in Skt. $g a(m)$-, Greek

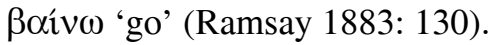

By now there was enough interpreted material available for Hirt (1893) to challenge the satem view of Phrygian. Hirt pointed out that all the examples showing $z$-reflexes of PIE voiced palatals had front vowel following the $z$.

Torp (1894: 5, 6) challenged Hirt's claim, saying there were obvious exceptions to Hirt's palatalization rule and there were names containing $z$ before back vowel (these were admittedly of unknown origin so neither argument was convincing) and that the similarity alleged by Plato (Kratylos 410A) between the Phrygian and the Greek words for 'dog' could be supported by a hypothetical Phrygian *sunes beside Greek kunes. Thus was originated a debate that continues to the present day: Neroznak (1976: 170) poured scorn on scholars like Meillet and Brugmann who maintained that not enough was known about Phrygian to discuss the matter, but years later Brixhe (1983: 170) still considered the question premature - and perhaps he was right. The most balanced view of the centum / satem question is basically a modification of Hirt's - that PIE palatals were palatalized in Phrygian before front vowel as in some centum languages, see, e.g., Bednarczuk (1986: 482).

This question is of course only just separable from the question of which languages within Indo-European are most closely related to Phrygian, which has also been hotly debated. A turning point in this debate was Kortlandt's (1988) demonstration on the basis of shared sound changes that Thraco-Armenian had separated from Phrygian and other originally Balkan languages at an early stage. The consensus has now returned to regarding Greek as the closest relative.

Ramsay's corpora seem to have inaugurated a thin stream of quite lengthy scholarly articles and some books. It is not possible here to recapitulate the mass of questions these works address. A few of the more prominent details will have to suffice. 
Thus in addition to challenging Hirt, Torp (1894: 10, 17) also proposed,

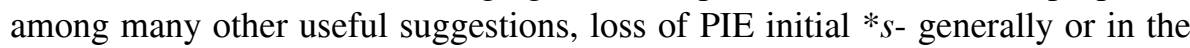
initial cluster $* s w$ - in Phrygian - we now believe $*_{s-}$ lost only in $*_{s w}-$ - and identification of the connective ... ke ... ke '... and ...' in NPhr. no. 12 (and

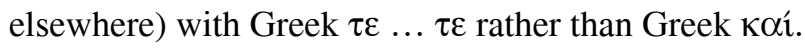

Kretschmer's Einleitung in die Geschichte der griechischen Sprache ("Introduction to the history of Greek") is still regarded as a seminal work on many aspects of Phrygian studies, despite a number of oddities such as the belief that PIE *e remains in Phrygian (Kretschmer 1896: 222). Kretschmer therefore missed an opportunity when he noted that Phrygian stems in -av- (proitavos, akenanogavos) were reminiscent of Greek stems in $-\eta F$ - but denied they could be connected (Kretschmer 1896: 237).

Solmsen, in two papers published in 1897, compared NPhr. vi with Russ. $n i$ '-ever,' proposed that NPhr. $\alpha \imath v \imath$ means 'and' or 'or' (Solmsen 1897a: 67f.) and invoked Lydian kan- in Kóv $\delta o v \lambda o \varsigma$ to explain Plato's remark about the 'dog'

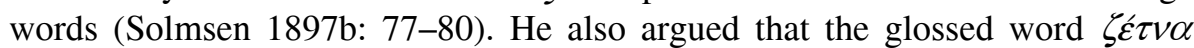
'gate' cannot go with the pure velar root *ghed- 'seize' but must reflect the palatal in *ghed- 'defecate;' Engl. gate can go with either, so the gloss $\pi v i \lambda \eta$ does not need to be emended to $\pi v \gamma \eta$ ' 'rump, buttocks.'

There were new contributions by archaeologists such as von Reber (1897: 564-585), who proposed eminently sensible interpretations of some well known OPhr. inscriptions and less extravagant though remarkably precise dates for the Midas and Areyastis monuments (ca. 600 BCE and 546 BCE, resp.); and Alfred Körte, who in 1898 provided corrections to existing readings of some inscriptions (Körte 1898: 84-118) and in 1904 (with Gustav Körte) commented on the confusion in the numbering and identification of some of Ramsay's 1883 corpus (A. Körte, G. Körte 1904: 19f.); and Brandenburg (1906: 637, 645), who noted that approximate decipherment of some inscriptions had been achieved and also gave a slightly better reading of one of Mordtmann's Midas graffiti (M-01d).

In 1898 Saussure published a chapter on the OPhr. inscriptions observed in Pteria by E. Chantre in the latter's account of his and his wife's doings in Cappadocia (cited here according to the reprint in Saussure 1922: 542-575). Thanks to these inscriptions Saussure was able to identify Hamilton's Pteria inscription as Phrygian (Saussure 1922: 544). He also observed that OPhr. ios ni (P-04) was the same as in NPhr. and recognized the suffix of Arkiaevais (M-01a) in Kanutievais (P-03) (ibid.), proposing that this suffix was used to generate patronymics or metronymics or gentilics (Saussure 1922: 549). Saussure also deduced, apparently independently of Torp, that $k e=$ Greek $\tau \varepsilon=$ (Saussure 1922: 551553) and cast doubt on Mordtmann's (1862: 20) by then traditional reading $z$ of the OPhr. Z-like character (with vertical central bar), and its mirror image, by suggesting it might also on occasion be read as yod (Saussure 1922: 575 n. 2).

Anderson, in a couple of papers published in 1897-98 and 1899, in addition to publishing facsimiles of some very precisely located NPhr. inscriptions also discovered the fem. sg. acc. of the relative pronoun in $\mu \alpha \nu \kappa \alpha \nu$ i $\alpha \nu \varepsilon \sigma \tau \alpha \varepsilon \zeta$ as 'the monument which (s/he) set up' and noted that confusion of gen. and dat. is 
common in the Greek inscriptions of Phrygia as well as in the NPhr. ones (Anderson 1899: 288).

There were some misunderstandings along the way: Kretschmer was sent a copy of an inscription he knew quite well (M-02) but the copy, by the explorer von Diest, was so extraordinarily bad that he failed to recognize it and in 1899 he wrote it up as a new inscription (Kretschmer 1899: 352; see also von Diest 1898: 33f.) Two years passed before Kretschmer realized his mistake and published a correction.

In his 1899 paper Kretschmer also proposed that -vais was an ethnic suffix and demonstrated the untenability of Torp's translation 'with his household and in person' of the frequent NPhr. phrase $\mu \varepsilon \zeta \varepsilon \mu \varepsilon \lambda \omega \varsigma \kappa \varepsilon \delta \varepsilon \omega \varsigma \kappa \varepsilon$, proposing instead '(cursed) by heaven and earth' (Kretschmer 1899: 357, 358 n. 2). This is similar to Ramsay's (1905: 107f.) and Lubotsky's (1998: 419f.) 'among gods and men.' In 1901 Kretschmer at last also identified the lambda-like letter in the last word of M-01b and M-02, as delta, as in M-01a, thus reading uniformly edaes instead of the variants egaes or elaes (Kretschmer 1901: 116).

In 1905 Ramsay updated his corpus of NPhr. inscriptions, adding another 19 and removing some that had been discovered to be in Greek. He appended a list of regions in which NPhr. inscs. are found which showed them to be rural and hence the preserve of the less educated (Ramsay 1905: 84f.). He cited Sayce's claim that the standard curse consists of two hexameters (Ramsay 1905: 85).

Meister's 1909 paper on Aeolian demonstratives ôve, etc. and Phrygian vt is of historical importance for its extensive if still partly controversial contributions to Phrygian phonology and morphology: it has many examples of $* \bar{o}>u, o v$ (Meister 1909: 317 n. 2); it was the first to propose mediae $>$ tenues (except $* g^{w}$

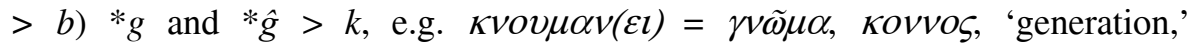

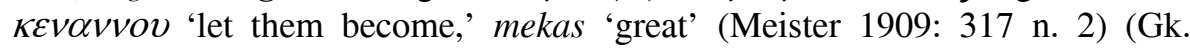
$\gamma \delta v o \varsigma, \gamma \varepsilon v-\mu \varepsilon \dot{\varepsilon} \gamma \varsigma \varsigma$ ); he proposed that the normal loss of final $-t$ as in edaes meant that $\alpha \delta \delta \alpha \kappa \varepsilon \tau$ is present not preterite (Meister 1909: 317 n. 3). Some ideas were less happy. e.g. Meister explained the alternation $\overline{\mathrm{e}} / \overline{\mathrm{a}}$ in matar materan by the supposed similarity of the two sounds in Phrygian, hence, allegedly, matar, anar, daditi for *meter, *aner, *dediti and ae in edaes, estaes (Meister 1909: 316 fn. 1).

The year 1911 saw the start of a new Corpus of NPhr. by Calder published in the JHS and completed by further instalments in 1913 and 1926 both with constant updating of inscriptions already published. Calder and Ramsay had amassed another score of NPhr. inscriptions during their several journeys to Phrygia. In his introductory essay, Calder notes some regional peculiarities in the wording of the execration formulae, but unfortunately in updating Ramsay's 48 texts he does not repeat Ramsay's information about their provenance. The rest of the Corpus receives much better treatment. The last instalment was followed immediately by Sayce's enthusiastic reception of the whole and suggestions for improvements, including improvements to Ramsay's OPhr. inscriptions which had been partly achieved by Ramsay himself: at last the reading edaes was confirmed for the former mixture of this with elaes and egaes. 
After Calder's first instalment Fraser published the first synthesis in 1913, concentrating almost exclusively on NPhr. and acknowledging Calder's explanations of the inscriptions as the most convincing produced so far. Fraser followed a history of research with a discussion of the curse formula; a detailed (satem) historical phonology rejecting Meister's devoicing of mediae; morphology; discussion of the meaning and origin of selected lexica; discussion of difficult parts of inscriptions, nos. 35 and 15; and word index - Phrygian, Indo-Iranian, Greek, etc.

In 1927, the year following the conclusion of Calder's Corpus, Jokl's influential article on the Phrygian language appeared in vol. 10 of Ebert's Reallexikon der Vorgeschichte. Among much else this has an excellent treatment of the problems of Phrygian historical phonology with many, many examples. It is here that I have noticed the first reference to the sound change PIE $* \bar{e}>$ Phrygian $a$, still ignored by Gusmani (1959: 18) and by Diakonov / Neroznak (1985: 43) and by Neroznak (1992: 273).

The year after that (1928) saw the publication of Calder's first volume in the series Monumenta Asiae Minoris Antiqua of which this first vol. as well vols. 4, 6, 7 and 8 are of direct relevance to NPhr. They contain edited texts and photographs and some drawings of the NPhr. inscriptions embedded in a mass of Greek inscriptions. Only a few of the photos of the Phrygian material are reasonably legible; many are essentially illegible. Most of the originals of the NPhr. inscriptions have now been lost. In view of the Prolegomena articles published by Brixhe (1994b) and Brixhe, Drew-Bear (1999), I understand there may be new corpus of NPhr. in preparation.

In 1932 Friedrich produced his very handy and frequently cited compendium of texts from Asia Minor.

1941 saw the publication of the much cited encyclopedia article of the same Friedrich.

In 1938 Haas began publishing a series of papers investigating inscriptions in both NPhr. and OPhr. as well as the glosses, and the names, and a host of other matters. This culminated in his book of 1966 which is regarded as a major landmark in Phrygian studies. Some would say this assessment owes more to the stimulus the book provided to further studies than for the intrinsic quality of Haas's innovations. Interestingly enough, though, the NPhr. section of the new online corpus of Phrygian inscriptions being prepared by Alexander Lubotsky takes Haas's conveniently assembled NPhr. corpus as basic. Some of Haas's conclusions have been firmly rejected by later scholars, such as his belief that the term "Phrygian" covered at least three distinct linguistic entities. Haas is also widely criticised for excessive and wild use of etymology in interpreting the texts, but I believe I'm not alone in thinking there is a good deal in Haas's work that is actually sounder than much that has been produced by some of his more strident detractors. A planned second volume containing an etymological dictionary and bibliography never came to fruition: after producing another half dozen publications on Phrygian, Haas died in 1977. For a brief but balanced 
evaluation of Haas' merits and demerits see his fellow Austrian (Fritz Freiherr) Lochner von Hüttenbach 1982. ${ }^{3}$

While Haas was still gathering momentum for his book another synthesis came out almost without warning in 1958-1959 from the pen of Gusmani in the form of four journal articles, subsequently issued as a book but retaining the original pagination. It contains a collection of 36 glosses based on Friedrich 1941, an alphabetical list of the most securely interpreted OPhr. lexemes, a treatment of the NPhr. execration formula as well as the rarer types of NPhr. texts, it augments Friedrich's 1932 catalogue of NPhr. inscriptions by a further 19 texts drawn from MAMA 4, 6, 7, and Am J Arch 36. Controversial glosses are allotted a special section as are Phrygian onomastics, Greek as spoken in Phrygia, and Phrygian historical phonology and morphology. Notably, Gusmani still believed PIE $* \bar{e}>\mathrm{i}$ and noted occasional devoicing of mediae, together with examples of palatals yielding both sibilants and velars.

After Haas 1966 there was a considerable upsurge of interest in Phrygian. Part of this was due to a sudden large increase in the number of OPhr. texts available due to the efforts of a number of archeologists, both Turkish and German - and especially the American Rodney Young who had begun excavating at Gordion in 1950, publishing a series of reports every other year or so containing among other things good photographs of the inscriptions that came to light together with some attempts at interpretation (see, e.g. Young 1964 n. 7). By 1969 he had amassed enough material to prepare a corpus of Gordion texts complete with photographs and drawings of the inscriptions as well as readings and limited interpretations. His purpose in doing this was to illustrate the evolution of the OPhr. alphabet. This work almost coincided with the preparation by Lejeune (1969a) of his major determinations on the alphabet, including the following:

(1) \& (2), as Ramsay had foreshadowed, $l$ had an acute angle and $g-$ a right angle; and the priority of the Greeks over the Phrygians in adopting the alphabet;

(3) that the OPhr. Z-like sign had the single value $y$ (IPA [j]) whatever its orientation, never $z$ (pace Haas [1966: 178f.] who, improving on Saussure [above], proposed that OPhr. $y$ and $z$ were mirror images of each other);

(4) $y$ is not found in inscriptions before the the $6^{\text {th }}$ century;

(5) $y \mathrm{C}$ is always separated by word boundary.

All this constitutes one of the first major advances post-Haas 1966 and in my view ushers in the modern period in which there is quite a plethora of publications on the subject. Among the more notable are:

The magnifient Brixhe / Lejeune Corpus of OPhr. inscriptions of 1984 with good photos of nearly all the inscriptions and / or squeezes of them, as well as drawings, readings, conservative attempts at interpretation and massive documentation. The book also introduces a new numbering system allowing the in-

\footnotetext{
${ }^{3}$ Haas 1966 was reviewed by Gusmani (1967), Brixhe (1968), Dressler (1968), Heubeck (1969), D'jakonov (1972).
} 
scriptions to be classified according to provenience and material (i.e. stone or portable utensil). Some of the more direct responses to it are:

(1) A review by Bajun / Orel (1986) claiming the authors' interpretation of 'OPhr.' was too narrow; (2) Georgiev (1985) describing the work as "magnifique" and giving a brief morphology, a vocabulary and interpretations of several of the OPhr. texts; and (3) Perpillou's (1986) article Le paléo-phrygien, dans son obscure vérité - apparently a pessimistic view of the potentials of OPhr. research.

Rather less worthy, despite the massive effort and ingenuity involved, are a couple of attempts by Soviet scholars to provide complete translations of the entire Phrygian corpus viz. Diakonoff / Neroznak in 1985 and Bajun / Orel in 1988(a), both of which incorporate some unorthodox views of Phrygian phonology and have more than their fair share of bizarre interpretations. Orel's book of 1997 marks a return to a more orthodox phonology and a decrease in the number of bizarre translations. The book is well organized and a handy reference for the entire corpus, but in my opinion the renumbering of the NPhr. material in line with the system of locality prefixes devised for OPhr. by Brixhe / Lejeune (1984) has not been sufficiently thought through.

Some further momentous events are:

(1) The 1995 First International Symposium on Phrygian published by Gusmani et al. (1997); and

(2) Brixhe's (2004b) second Supplement to Brixhe / Lejeune (1984).

Of the literature published since Haas 1966, I think for anyone investigating the interpretation of the inscriptions the following authors are required reading: Lejeune, Neumann, Brixhe, Lubotsky, Gusmani, Kowal, Heubeck, Janda. Bajun and Orel should also not be neglected and one should at least be aware of the contributions of Diakonov and Neroznak, bearing in mind that few serious efforts are entirely without merit.

Recently some old problems of historical phonology have been readdressed, such as the question of devoicing of PIE mediae by Lubotsky (2004), Matzinger (2006) and Woodhouse (2006), the question of palatalization of tectals by Woodhouse (2005) and other papers of mine that resulted in my being invited here; and last but not least your own Dr Sowa's papers on Balkan IE, apparent Phrygian words in Greek and a systematized catalogue of Phrygian verb forms.

The situation of Phrygian is very similar to that of Lydian. If anyone is looking for a $\mathrm{PhD} /$ Kandidat project, I think there is probably room for a book like Gusmani's Lydisches Wörterbuch that would contain not the biased conclusions of one scholar but an annotated compendium of whatever useful interpretations have been advanced for each interpreted word that has been divined in the corpus or corpora.

I should like to finish by echoing the sentiments of Neumann (1987: 93) and Lubotsky (1997: 115) that further progress in elucidating the Phrygian texts needs to be based on a combination of paleographic and combinatorial analysis with a constant eye on the Greek inscriptions of Phrygia and a minimal reliance on etymology. The temptation to sin against these provisions is of course strong: 
I regret to say that I myself have succumbed to this temptation on more than one occasion.

\section{References 4}

Akurgal E. 1943. Pazarlı'da çıkan eserler üzerinde yeni araştırmalar. - Türk tarih kurumu belleten 7: 1-22 [in Turkish], 23-43 [in German].

- 1955. Phrygische Kunst. Ankara.

- 1961. Die Kunst Anatoliens von Homer bis Alexander. Berlin.

- 1970. Ancient civilizations and ruins of Turkey. Istanbul.

- 1983. Das dunkle Zeitalter Kleinasiens. - Deger-Jalkotzy S. (ed.): 67-78.

Anderson J.G.C. 1897. A summer in Phrygia. - JHS 17: 396-424.

- 1898. A summer in Phrygia. - JHS 18: 81-159, 340-344.

-1899. Exploration in Galatia cis Halym. [part II Topography, epigraphy, Galatian civilization]. - JHS 19: 52-134; 280-318. [pp. 52-134 misfiled under Crowfoot].

Bader F. 1982. Autour du réfléchi anatolien: étymologies pronominales. - BSL 77: 83-155.

Bajun L.S. 1992. A Phrygian word in Hieroglyphic Luwian. - Journal of Ancient Civilizations 7: 131-139.

Bajun L.S., Orel V.È. 1987. Novofrigijskie ètjudy III. - Linguistique balkanique 30.3: 175$-176$.

- 1988a. Jazyk frigijskih nadpisej kak istoričeskij istočnik. - Vestnik drevnej istorii 1988.1: 173-200.

- 1988b. Jazyk frigijskih nadpisej kak istoričeskij istočnik. - Vestnik drevnej istorii 1988.4: 132-168.

- 1988c. The 'Moesian' inscription from Uyučik. - Kadmos 27.2: 131-138.

- 1989a. Starofrigijskij glagol'nyj stroj v sravnitel'no-istoričeskom osveščenii. - Slavjanskoe i balkanskoe jazykoznanie 1989: 225-238.

- 1989b. Frigijsko-anatolijskie jazykovye otnošenija. - Paleobalkanistika i antičnost': sbornik naučny trudov. Moskva: 24-33.

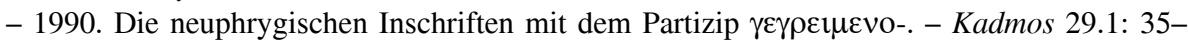
$-37$.

- 1991. The inscription from Sitovo. - Orpheus 1: 144-148.

- 1992 / 1993. Paleo-Balkanic epigraphic monuments: new discoveries and interpretations. - FOr 29: 5-17.

- 1993a. Lingvstičeskaja i kul'turno-istoričeskaja interpretacija Sitovskoj nadpisi. - Vestnik drevnej istorii 1993.1: 126-135.

Bakir T., Gusmani R. 1991. Eine neue phrygische Inschrift aus Daskyleion. - EpAnatol 18: 157-164. [B-04].

- 1993. Graffiti aus Daskyleia. - Kadmos 32.2: 135-144.

Barnett R.D. 1967. Phrygia and the peoples of Anatolia in the Iron Age. - Cambridge Ancient History II: ch. XXX.

- 1975. Phrygia and the peoples of Anatolia in the Iron Age. - Cambridge Ancient History. II.2: 417-442. [ $3^{\text {rd }}$ ed.]

Bayun L.S. see Bajun L.S.

Bednarczuk L. 1986. Język frygijski. - Leszek Bednarczuk (ed.) Języki indoeuropejskie 1. Warszawa: 481-485.

\footnotetext{
${ }^{4}$ Although this bibliography makes no claim to being exhaustive it nevertheless does contain many items not specifically mentioned in the lecture. Some journal articles were not available to the author and remain here without title.
} 
Beekes R.S.P. 1987. The PIE words for 'name' and 'me'. - Sprache 33: 1-12.

Bittel K. 1934. Die Felsbilder von Yazllıkaya. - Istanbuler Forschungen 5.

- 1942. Kleinasiatische Studien. Istanbul.

- 1983. Die archäologische Situation in Kleinasien um 1200 v. Chr. und während der nachfolgenden vier Jahrhunderte. - Deger-Jalkotzy S. (ed.): 25-47.

Bittel K., Güterbock, H.G. 1935. Boğazköy: neue Untersuchungen in der hethitischen Hauptstadt 1. Berlin.

Bonfante G. 1939-1944. 'Sabadios-svoboda', le libérateur. - AnnIPhO 7: 41-46.

- 1946. Armenians and Phrygians. - Armenian Quarterly 1: 82-97.

- 1988 [1989]. Il nome dei Frigi e la deaspirazione di *GH, *H. - Onomata 12: 120-121.

Brandenburg E. 1906. Neue Untersuchungen im Gebiet der phrygischen Felsfassaden. Abhandlungen der Historischen Klasse der Königlich-Bayerischen Akademie der Wissenschaften 23: 637-716.

Brixhe C. 1968. Un ouvrage sur la langue phrygienne. - Revue de Philologie 42: 306-319.

- 1974. Reflexions sur phrygien 'iman'. - Mélanges A.M. Mansel 1: 239-250.

- 1975. Problèmes d'interpretation du phrygien, in Le déchiffrement des écriture et des langues. - Colloque du XXIX Congrès international des Orientalistes [Paris, juillet 1973, présenté par J. Leclant]: 65-74.

- 1978a. Études neo-phrygiennes I. - Verbum 1/ 1: 1-22.

- 1978b. Études neo-phrygiennes II. - Verbum 1/2: 3-21.

- 1979a. Études neo-phrygiennes III. - Verbum 2 / 2: 177-192.

- 1979b. Le nom de Cybèle. L'antiquité avait-elle raison? - Sprache 25: 40-45.

- 1980. (rev.) Heubeck A. 1979. - KZ 94: 289-291.

- 1981. Inscriptions: les graffites du grand tumulus [appendix I]. - Young R.S. (ed.) Three great early tumuli. Philadelphia: 273-277.

- 1982. Palatalisations en grec et en phrygien: problèmes phonétiques et graphiques. - BSL 77: 209-249.

- 1983. Épigraphie et grammaire du phrygien: état présent et perspectives. - Vineis E. (ed.) Le lingue indoeuropee di frammantaria attestazione. [Atti del Convegno della Società Italiana di Glottologia e della Indogermanische Gesellschaft, Udine, 22-24 settembre 1981]. Pisa: 109-133.

- 1989 / 1990. La plus occidentale des inscriptions phrygiennes. - Incontri linguistici 13: 6167.

- 1991. Les inscriptions paléo-phrygiennes de Tyane: leur intérêt linguistique et historique. La Cappadoce Méridionale jusqu'à la fin de l'époque romaine. État des recherches. Paris: 37-46.

- 1993. Du paléo- au néo-phrygien. - Comptes rendus des seances de l'Academie des Inscriptions et Belles-Lettres 2: 323-344.

- 1994a. Le phrygien. - Bader F. (ed.) Langues indo-européennes. Paris: 165-178.

- 1994b. Prolégomènes au corpus néo-phrygien, communication au colloque: Grec et langues i.e. d'Asie Mineure. Paris.

- 1996. Les documents phrygiens de Daskyleion et leur éventuelle signification historique. Kadmos 35: 125-148.

- 1997. Les clitiques du néo-phrygien. - Gusmani et al. (eds.): 41-70.

- 2002. Achéens et Phrygiens en Asie Mineure: approche comparative de quelques donées lexicales. - Novalis Indogermanica: Fs Günter Neumann zum 80. Geburtstag. Graz: 49-73 .

- 2004a. Phrygian. - Woodward R.D. (ed.) The Cambridge encyclopedia of the world's ancient languages. Cambridge: 777-788.

- 2004b. Corpus des inscriptions paléo-phrygiennes, Supplément II. - Kadmos 43: 1-130. 
Brixhe C., Drew-Bear Th. 1978. Un nouveau document neo-phrygien. - Kadmos 17 / 1: 50$-54$.

- 1982. Trois nouvelles inscriptions paléo-phrygiennes de Çepni. - Kadmos 21: 64-97.

- 1997. Huit inscriptions néo-phrygiennes. - Gusmani et al. (eds.): 71-114.

- 1999. Prolégomènes au corpus néo-phrygien. - BSL 94: 285-315.

Brixhe C., Lejeune M. 1984. Corpus des inscriptions paléo-phrygiennes. [2 vols]. Paris.

Brixhe C., Neumann G. 1985. Découverte du plus long texte néophrygien: l'inscription de Gezler Köyü. - Kadmos 24: 161-184.

Brixhe C., Panayotou A. 1995. Les Grecs, les Phrygiens et l'alphabet. - Fol A. et al. (eds.) Studia in honorem Georgii Mihailov. Sofia: 101-114.

Brixhe C., Sivas T. 2003. Exploration de l'ouest de la Phrygie: nouveau documents paléophrygiens. - Kadmos 42: 65-76.

Brixhe C., Waelkens M. 1981. Un nouveau document neo-phrygien au Musée d'Afyon. - Kadmos 20.1: 66-75.

Buckler W.H., Calder W.M. 1939. Monumenta Asiae Minoris antiqua, 6: Monuments and documents from Phrygia and Caria. Manchester.

Buckler W.H., Calder W.M., Guthrie W.K.C. 1933. Monumenta Asiae Minoris Antiqua, 4: Monuments and documents from Eastern Asia and Western Galatia. Manchester.

Būga, K. 1959. Rinktiniai raštai, 2. Vilnius.

Calder W.M. 1911. Corpus inscriptionum neo-phrygiarum [I]. - JHS 31: 161-215.

- 1913. Corpus inscriptionum neo-phrygiarum II. - JHS 33: 97-104.

- 1923. The medial verbal $-r$ termination in Phrygian. - Journal of the Manchester Egyptian and Oriental Soc. 10: 25-33.

- 1926. Corpus inscriptionum neo-phrygiarum III. - JHS 46: 22-28.

- 1928. Monumenta Asiae Minoris Antiqua, 1. Manchester.

- 1956. Monumenta Asiae Minoris antiqua, 7: Monuments from Eastern Phrygia. Manchester.

Calder W.M., Cormack J.M.R. [with contributions from Ballance M.H. and Gough M.R.E]. 1962. Monumenta Asiae Minoris Antiqua, 8: Monuments from Lycaonia, the PisidoPhrygian borderland, Aphrodisias. Manchester.

Carnoy A. 1959. Échanges thraco-phrygiens entre $b$ et $m$. - Muséon 72: 207-216.

Carruba O. 1980. Studi micenei ed egeo-anatolici. - SMEA 22: 292-295.

Chantre E. 1898. Recherches archéologiques dans l'Asie occidentale: mission en Cappadoce 1893-1894. Paris.

Çınaroğlu A., Varinlioğlu E. 1985. Eine neue altphrygische Inschrift aus Tyana. - EpAnat 5: $5-11$.

Cox C.W.M., Cameron A. 1932. A native inscription from the Myso-Phrygian borderland. Klio 25: 34-49.

Crevatin F. 1972. Note Frigie I: norikon 'otre'. - KZ 86: 178-189.

- 1973. Note Frigie II: "Belta”. - KZ 87: 207-214.

Crossland R.A. 1971. - The position of the Indo-European language family of Thracian and Phrygian and their possible close cognates: some general observations. - Studia Balcanica 5: 225-236.

Darga M. 1993. Fouilles de Şarhöyük-Dorylaion (1989-1992). - XV. Kazi sonuçları toplantısı (Ankara 1993). Ankara: 481-501.

Deger-Jalkotzy S. (ed.) 1983. Griechenland, die Ägäis und die Levante während der "Dark Ages" [Akten des Symposiums von Stift Zwettl (NÖ.) 11/-14. Oktober $1980=$ Sitzungsberichte der Österreichen Akademie der Wissenschaften, philosophischhistorische Klasse, 418 = Veröffentlichungen der Kommission für mykenische Forschung 10]. Vienna.

Diakonoff I.M. = D’jakonov I.M. 
von Diest W. 1898. Von Tilsit nach Angora. [Dr. A. Petermanns Mitteilungen aus Justus Perthes geographischen Anstalt (Gotha), Ergänzungsheft 125].

Dinç Rafet, Innocente L. 1999. Ein Spinnwirtel mit phrygischer Inschrift. - Kadmos 38: 65-72 .

D’jakonov I.M. 1961 Hetty, frigijcy i armjane. - Peredneaziatskij sbornik. Moscow.

- 1972. (rev.) Haas 1966. - Pervyj simpozium po balkanskomu jazykoznaniju. Moscow: 3$-8$.

- 1976. Mesto frigijskogo sredi indoevropejskih jazykov. - Drevnij vostok 2. Yerevan: 158$-164$.

- 1977. On Cybele and Attis in Phrygia and Lydia. - AAntH 25: 333-340.

D'jakonov I.M., Neroznak V.P. 1977. Očerk frigijskoj morfologii. - Baltistica 2. [priedas = supplement]: 169-198.

- 1985. Phrygian. (Anatolian and Caucasian studies). Delmar (New York).

Dressler W. 1964a. Altkleinasiatische Miszellen. - Sprache 10: 110-115.

- 1964b. Armenisch und Phrygisch. - Handes Amsorya 78: 486-498.

- 1968. (rev.) Haas 1966. - Sprache 14: 40-49.

- 1969. Eine textsyntaktische Regel der idg. Wortstellung. - KZ 83: 1-25.

Drew-Bear Th. 1978. Nouvelle inscriptions de Phrygie. Zutphen.

Drew-Bear Th., Naour Ch. 1990. Divinités de Phrygie. - ANRW II 18.3: 1907-2044.

Dunbabin T.J. 1957. The Greeks and their eastern neighbours. London: 62-71 [esp.].

Dunst G. 1963. Г $\alpha \lambda \lambda \alpha \rho 0$. - KZ 78: 147-152.

Duridanov I. 1993. Brygischer Spuren im thrakischen Sprachgebiet. - Orpheus 3: 63-68.

Džaukjan =Jahukyan

Fick A. 1873. Die ehemalige Spracheinheit der Indogermanen Europas. Göttingen.

- 1889. Zum Phrygischen. - Beiträge zur Kunde der indogermanischen Sprachen 4: 50-51.

Fauth W. 1977 [1978]. Phryg. 'A $\delta \alpha \mu \nu \alpha$ im Aiis-Hymnos der Naassener? - IF 82: 80-96.

- 1989. Mykenisch du-ma, phrygisch dum-. - HS 102: 187-206.

Fraser J. 1913. Transactions of the Cambridge Philological Society 6 / 2: 1-48. [appears to have no other title]

Frei P. 1986. АN $\triangle \mathrm{I} \Sigma \Sigma \mathrm{H}$ BONOKIATEI: altphrygisches Sprachgut in einer griechischen Weihinschrift aus dem Archächologischen Museum von Eskişehir. - A. Etter A. (ed.) O-o-pe-ro-si: Fs Ernst Risch zum 75. Geburtstag, Berlin, New York: 707-717.

- 1988. Phrygische Toponymie. - Ep Anat 11: 9-34.

- 1990. Untersuchungen zu den Ortsnamen Phrygiens. - X. Türk Tarih Kongrsi'den ayribasım. Ankara: 185-195.

- 1992. Die epichorischen Namen im griechisch-römischen Inschriftenbestand der Region von Eskişehir. - Otten H. (ed.). Hittite and other Anantolian and Near Eastern studies in honour of Sedat Alp. Ankara: 181-192.

Friedrich J. 1932. Kleinasiatische Sprachdenkmäler. Berlin.

- 1941. Phrygia (Sprache); Phrygia (Geschichte). - Pauly-Wissowa Real-encyclopädie der classischen Altertumswissenschaft. Stuttgart. XX / 1 = Halbband 39: 868-882; 882-891.

- 1965. Ein phrygisches Siegel und ein phrygisches Tontafel. - Kadmos 4: 154-156.

Georgiev V.I. 1937. Eine gemeinsame Lauteigentümlichkeit des Albanischen, Phrygischen, Armenischen und das Guttural problem. - KZ 64: 104-126.

- 1958. Issledovanija po sravnitel'no-istoričeskomu jazykoznaniju. Moscow.

- 1973. Die ethnischen Verhältnisse im alten Nordwestkleinasien. - Ling. Balk. 16 / 2: 5-12.

- 1981. Introduction to the history of the Indo-European languages [ $3^{\text {rd }}$ ed.]. Sofia.

- 1985. Le paléo-phrygien. - Ling. Balkanique 28: 5-8.

Gindin L.A. 1981. Drevnejšaja onomastika Vostočnyh Balkan. Sofia. 
Graaf F. de. 1989. Midas wanax lawagetas. - Best J.G.P., Nanny M.W. de Vries (eds.). Thracians and Mycenaeans: Proceedings of the Fourth International Congress of Thracology. [Rotterdam, 24-26 September 1984]. Leiden: 153-155.

Graf F. 1998. Interpretation, II: Religion. - Cancik H., Schneider H. (eds.). Der neue Pauly: Enzyklopädie der Antike, 5. Stuttgart, Weimar: 1041-1043.

Gusmani R. 1958a. Studi sull'antico frigio: la populazione, le glosse frige presso gli antichi. - RILSL 92 [= Rendiconti dell'Istituto Lombardo, Classe di Lettere]: 835-869.

- 1958b. Le iscrizioni dell' antico frigio. - RILSL 92: 870-903.

- 1958c. Monumenti frigi minori e onomastica: tipi di iscrizioni neofrige diversi da quello deprecatorio. - RILSL 92: 904-928.

- 1959a. Il frigio e le altre lingue indeuropee: ricostruzione delle caracteristiche fonetiche e morfologiche del frigio. - RILSL 93: 17-49.

- 1959b. Studi frigi. Milan [= 1958a, b, c + 1959a].

- 1959c. Relazioni linguistiche tra Frigia e Licia. - Arch. Glottol. Ital. 44: 9-16.

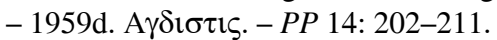

- 1962. Прıßı (anthroponyme) et néo-phrygien prieje. - AION-L 4: 48-52.

- 1967. Rev. of Haas 1966. - IF 72: 232-238.

- 1978. - Annali Sc. Norm. 3.8: 833.

- 1985. Microasiatica. - Incontri linguistici 10: 107-112.

- 1988. An epichoric inscription from the Lydio-Phrygian borderland. - Studi di storia e di filologia anatolica dedicati a G. Pugliese Carratelli. Florence: 67-73.

Gusmani R., Bakır T. 1991. Eine neue phrygische Inschrift aus Daskyleion. - Epigraphica Anatolica 18: 157-164.

Gusmani R., Poetto M. 1981. Un nuovo sigillo frigio iscritto. - Kadmos 20: 64-67.

Gusmani R., Polat G. 1999. Manes in Daskyleion. - Kadmos 38: 137-162.

Gusmani R., Polat Y. 1999. Ein neues phrygisches Graffito aus Daskyleion. - Kadmos 38: 59-64.

Gusmani R., Salvini M., Vannicelli P. (eds.) 1997. Frigi e frigio: Atti del $1^{\circ}$ Simposio Internazionale [Roma, 16-17 ottobre 1995]. Roma.

Haas O. 1938. Zur Erklärung der neuphrygischen Inschriften. - Wiener Zeitschrift für die Kunde des Morgenlandes 45: 121-134.

- 1939. Über die phrygischen Sprachreste und ihr Verhältnis zum Armenischen. - Handes Amsorya 53: 225-235.

- 1951. Zur Deutung der phrygischen Inschriften. - RHA 11 [fasc. 53]: 1-30.

- 1955. Altkleinasiatische Elemente im Phrygischen, Anadolu araștırmaları. - JbKAF 3/1: 129-137.

- 1957. Die Sprachgeschichtliche Stellung des Phrygischen. - Ezikovedski izsledovanija $v$ čest na St. Mladenov. Sofia: 451-467

- 1958. Etymologien. - Sprache 4: 101-107 [esp.: 105-107].

- 1960a. Neue spätphrygische Texte. - Sprache 6: 9-32.

- 1960b. Die phrygische Sprache im Lichte der Glossen und Namen. - LBalk 2: 25-68.

- 1961a. Phrygische Inschriften. Berichtigte Lesungen - verbesserte Deutungen. - Sprache 7: 77-92.

- 1961b. Armenier und Phrygier. - LBalk 3: 29-65.

- 1961c. Handes Amsorya. Vienna 10 / 12: 563-612.

- 1961d. Lexikalische Anklänge an Slavisches in den Sprachen Kleinasiens und Griechenlands. - Godišnjak 2: 65-99.

- 1964. Das Phrygische und die Sprachen der Balkanländer. Die Kultur Südeuropas, ihre Geschichte und ihre Ausdrucksformen. - Südosteuropa-Schriften 6: 76-89.

- 1966. Die phrygischen Sprachdenkmäler. - LBalk 10.

- 1969. Neue phrygische Sprachdenkmäler. - KZ 83: 70-87. 
- 1970. Das Problem der Herkunft der Phryger und ihrer Beziehungen zu den Balkanvölkern. - Acta Antiqua Academiae Scientiarum Hungaricae 18: 31-69.

- 1971. Berichtigung (Zur altphrygischen Inschrift XXIX). - KZ 85: 296.

- 1976a. - Linguistique balkanique 19 / 3: 49-62.

- 1976b. Die Sprache der spätphrygischen Inschriften. - LBalk 19.3: 63-82; 19.4: 53-71.

Hamilton W.J. 1842. Researches in Asia Minor, Pontus and Armenia, 1. London.

Hajnal I. 2004. Vorbemerkungen zu einer Paleolinguistik des Balkanraums. - Bammesberger A., Vennemann T. (eds.) Languages in prehistoric Europe [2 $2^{\text {nd }}$ ed.], Heidelberg: $117-145$.

Hammond N.G. 1972. A history of Macedonia. London.

Hamp E.P. 1969. A Phrygian and Albanian preverb? - NTS 23: 13-14.

- 1993. Phrygian-gordum. - MSS 58: 89.

Haspels C.H.E. 1971. The highlands of Phrygia [2 vols.]. Princeton.

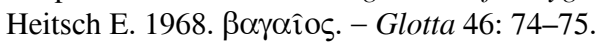

Hermann E. 1922. (rev.) Sieg E., Siegling W. (eds.) Tocharische Sprachreste 1. [of Königliche Preußische Turfanexpeditionen]. Tocharische Sprachreste, 1. - KZ 50: 296-314 .

Heubeck A. 1958. Bemerkungen zu den neuphrygischen Fluchformeln. - IF 64: 13-25.

- Rev. of Haas 1966. - Gnomon 39 / 6: 579-583.

- 1979. Schrift [= Archaeologia Homerica, 3, chapter X]. Göttingen. [esp.: 78].

- 1986a. Bemerkungen zur altphrygischen Inschrift T-03. - Kadmos 25 / 1: 74-78.

- 1986b. Bemerkungen zur spätphrygischen Inschrift Nr. 31. - Kadmos 25 / 1: 79-84.

- 1987. Phrygiaka I-III. - HS 100: 70-85.

Hirt H. 1893. Gehören die Phryger und Thraker zu den satem- oder centum-Stämmen? - IF 2: 143-149.

Innocente L. 1995. Stato degli studi frigi. - O. Carruba (ed.). Atti del II congresso internazionale di hittitologia. Pavia: 213-224.

- 1997a. Questioni di onomastica 'frigia'. - Gusmani et al. (eds.): 33-40.

- 1997b. Bibliografia frigia. - Gusmani et al. (eds.): 287-292.

J̌ahukyan G.B. [= Džaukjan, Gevork Beglarovič] 1970. Hayerena ev hndevropakan hin lezunera. Erevan.

- 1977. O refleksax indoevropejskih zadnejazyčnyh v frigijskom jazyke. - Kwartalnik Neofilologiczny 24: 207-216.

Janda M. 1997. Zur altphrygischen Areyastis-Inschrift. - Gusmani et al. (eds.): 271-277.

Jokl N. 1927. Phryger. A. Sprache. - Ebert M. (ed.) Reallexikon de Vorgeschichte 10: 141-153.

Katičić R. 1976. Ancient languages of the Balkans. The Hague, Paris.

Katz H. 1988. Zu den ' $r$-Endungen' des indogermanischen Verbs. - HS 101.1: 26-52.

Kirsten E. 1959. Pteria. - Pauly-Wissowa Real-encyclopädie des classischen Altertumswissenschaft. XXXIII. 2. Stuttgart: 2465-2466.

Klingenschmitt G. 1994. Die Verwandtschaftsverhältnisse der indogermanischen Sprachen. - Rasmussen J.E., Nielsen B. (eds.). In honorem Holger Pedersen: Kolloquium der Indogermanischen Gesellschaft vom 26. bis 28. März in Kopenhagen. Wiesbaden: 235-251.

Ködderitzsch R. 1985. Brygisch, Päonisch, Makedonisch. - LBalk 28: 17-41.

Körte A. 1898. Die phrygischen Felsdenkmäler. - Mitteilungen des deutschen archäologischen Instituts 23: 80-153.

Körte G., Körte A. 1904. Gordion: Erbegnisse der Ausgrabung im Jahre 1900 [Jahrbuch des deutschen archäologischen Instituts, Ergänzungsheft 5]. Berlin.

Kortlandt F. 1988. The Thraco-Armenian consonant shift. - LBalk 31.1-2: 71-74.

Kowal B. 1983. Versuche zur spätphrygischen Syntax. - Verbum 6.1-2: 93-100.

- 1984a. Zur spätphrygischen Inschrift 15. - KBS 10.1: 6-9. 
- 1984b. Zur spätphrygischen Inschrift 31. - Kadmos 23. 2: 180-185.

- 1988. Bemerkungen zur Syntax des Phrygischen. - Zinko Ch. (ed.). [Akten der 13. Österreichischen Linguistentagung, Graz, 27-27 Oktober 1985]. Arbeiten aus der Abt. "Vergleichende Sprachwissenschaft". Graz: 226-235.

Kretschmer P. 1896. Einleitung in die Geschichte der griechischen Sprache. Berlin $\left[2^{\text {nd }}\right.$ ed. 1970]. Göttingen.

- 1898. [no title], in von Diest: 34.

- 1899. Neue phrygische Inschriften. - Wiener Zeitschrift für die Kunde des Morgenlandes 13: 352-362.

- 1901. Zu der phrygischen Inschrift Bd. XIII, S. 352. - Wiener Zeitschrift für die Kunde des Morgenlandes 15: 115-116.

- 1927. Mytische Namen, (17. Hipta). - Glotta 15: 77-80.

- 1932. XӨஸ́v. - Glotta 20: 65-67.

- 1950. Die phrygische Episode in der Geschichte von Hellas. - Miscellanea Academica Berolinensia: 173-194.

Kroll W. 1932. Midas. - Pauly-Wissowa Real-encyclopädie des classischen Altertumswissenschaft. XV. 2. Stuttgart: 1526-1540.

Kuhrt A. 1995. Phrygia and Lydia, in the Ancient Near East c. 3000-300 B.C., 2 [Routledge History of the Ancient World]. London, NY: 562-573.

Lagarde P. de 1866. Gesammelte Abhandlungen. Leipzig.

Laminger-Pascher G. 1984. Beiträge zu den griechischen Inschriften Lykaoniens. [Ergänzungsb. zu TAM Nr. 11/ Denksch. Wien. 173]. Wien.

- 1989. Lykaonien und die Phryger. - Sitzungsberichte der Österreichischen Akademie der Wissenschaften 532.

- 1990. Lykaonien und die Ostgrenze Phrygiens. - EpAnat 16: 1-13.

Leake W.M. 1824. Journal of a tour in Asia Minor. London.

Lejeune M. 1966. La diffusion de l'alphabet. - CRAI 1966: 505-511.

- 1969a. Discussions sur l'alphabet phrygien. - Studi micenei ed egeo-anatolici [SMEA, Rome] 10: 19-47.

- 1969b. Notes paléo-phrygiennes. - Revue des études anciennes 71: 287-300.

- 1969c. A propos de la titulature de Midas. - Athenaeum 47: 179-192.

- 1970. Les inscriptions de Gordion et l'alphabet phrygien. - Kadmos 9: 51-74.

- 1972. A propos de la titulature de Midas. - Mémoires de philologie mycénienn, 3. Paris: 333-344.

- 1978. Sur l'alphabet paléo-phrygien. - Annali della Scuola Normale Superiore di Pisa, Classe di lettere e filosofia, Serie III 8.3: 783-790.

- 1979. Regards sur les sonores i.e. en vieux phrygien. - Florilegium anatolicum: mélanges offerts à Emmanuel Laroche. Paris: 219-224.

Lenschau 1942. Otys. - Pauly-Wissowa Real-encyclopädie des classischen Altertumswissenschaft. XVIII. 2. Stuttgart: 1889.

Lochner von Hüttenbach F. 1982. Der Anteil Österreichs an der Erforschung des Phrygischen. - Tischler J. (ed.) Serta indogermanica [Fs Günter Neumann]: 143-150.

Lubotsky A. 1988. The Old Phrygian Areyastis inscription. - Kadmos 27: 9-26.

- 1989a. New Phrygian $\varepsilon \tau \imath$ and $\tau$. - Kadmos 28: 79-88.

- 1989b. The syntax of the New Phrygian inscription No. 88. - Kadmos 28: 146-155.

- 1991. Rev. of Diakonoff / Neroznak 1985. - Bibliotheca orientalis 48: 225-230.

- 1993a. Word boundaries in the Old Phrygian Germanos inscription. - EpAnat 21: 93-98.

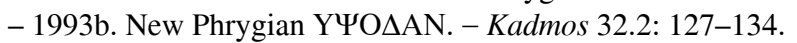

- 1997. New Phrygian inscription No. 48: paleographic and linguistic comments. - Gusmani et al. (eds.): 115-130. 
- 1998. New Phrygian metrics and the $\delta \varepsilon \omega \varsigma \zeta \varepsilon \mu \varepsilon \lambda \omega \varsigma$ formula. - Studies in honor of Calvert Watkins, Jasanoff J. et al. (ed.) Innsbruck: 413-421.

- 2004. The Phrygian Zeus and the problem of the "Lautverschiebung". - HS 117: 229-237.

Macrì Li Gotti M.V. 1977. Sum. LUGAL, frigio $\lambda \alpha$ F $\alpha \gamma \tau \alpha \varepsilon 1$ - Paideia 32: 239-240.

Mallory J.P. 1997. Phrygian language. - Mallory J.P., Adams D.Q. (eds.) Encyclopedia of Indo-European culture, London, Chicago: 418-420.

Marstrander C. 1929. Norsk Tijdsskrift for Sprogvidenskap, 2 [Oslo]: 290-305.

Masson O. 1979. A propos de divinités anatoliques: II. La prétendue déesse phrygienne 'Gda Ma'. - Florilegium anatolicum: mélanges offerts à Emmanuel Laroche. Paris: 245-247.

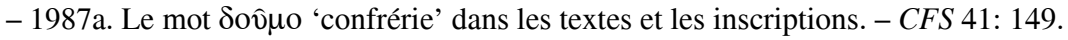

- 1987b. Le sceau paléo-phrygien de Mane. - Kadmos 26. 2: 109-113.

Matzinger J. 2005. Phrygisch und Armenisch. - Meiser G. et al. (eds.): 375-394.

- 2006. Interpretation sprachlicher Daten aus Rest- und Trümmersprachen: das Fallbeispiel der Streitfrage um eine phrygische Lautverschiebung. - HS 119: 190-210.

Meiser G., Hackstein O. (eds.) 2005. Sprachkontakt und Sprachwandel: Akten der XI. Fachtagung der Indogermanischen Gesellschaft, 17.-23. September 2000, Halle an der Saale. Wiesbaden.

Meister R. 1909. Die äolischen Demonstrativa őve, ővı, ővv und die Partikel vı (ve) im Phrygischen. - IF 25: 312-325.

- 1911. Beiträge zur griechischen Epigraphik und Dialektologie X: Kyprische Inschriften (mit einem Exkurs über die altphrygische Arezastis-Inschrift). - Berichte der Sächsischen Gesellschaft der Wissenschaft 63: 21-25.

- 1912. - Xenia Nicolaitana. Fs zur Feier des vierhundertjährigen Bestehens der Nikolaischule in Leipzig. Leipzig. [title of contribution and pages unknown, contains: 166, 174].

Mellink M.J. 1979. Midas in Tyana. - Florilegium anatolicum: mélanges offerts à Emmanuel Laroche. Paris: 249-257.

- 1981. Conclusions (chapter V). - Young R.S.: 269-272.

Meyer Ed. 1897. Bithynia: Bevölkerung [and] Bithynia: Geschichte. - Pauly-Wissowa Realencyclopädie des classischen Altertumswissenschaft. III. 1 Stuttgart: 507-514.

Mitchell S. 1980. Population and land in Roman Galatia. - ANRW II 7.2: 1053-1081.

- 1993. Anatolia: land, men and gods in Asia Minor. Oxford.

Monumenta Asiae Minoris Antiqua, 1: see Calder 1928.

Monumenta Asiae Minoris Antiqua, 4: see Buckler, Calder, Guthrie 1933.

Monumenta Asiae Minoris Antiqua, 6: see Buckler, Calder 1939.

Monumenta Asiae Minoris Antiqua, 7: see Calder 1956

Monumenta Asiae Minoris Antiqua, 8: see Calder, Cormack et al. 1962.

Mordtmann A.D. 1861. Bogazköi und Üjük. Dritter Beitrag zur vergleichenden Erdkunde von Kleinasien. - Sitzungsberichte der Königlichen Bayerischen Akademie der Wissenschaften zu München, philosophische-philologische Classe vom 9. Februar 1861: 169-198.

- 1862. Ueber die altphrygischer Sprache. - Sitzungsberichte der Königlichen Bayerischen Akademie der Wissenschaften zu München, philosophische-philologische Classe vom 4. Januar 1862: 12-38 [plus 2 plates].

Neroznak V. Petrovič 1976. K izučeniju frigijskogo jazyka: problemy i rezul'taty. - Drevnij vostok 2: 165-189.

- 1978. Paleobalkanskie jazyki. Moskva.

- 1989. K dešifrovke novonajdennoj frigijskoj nadpisi iz Gezler Këjju. - Paleobalkanistika i antičnost'. Sbornik naučnyh trudov. Moscow: 37-44.

- 1992. Phrygian. - Polomé E.C., Winter W. (eds.) Reconstructing languages and cultures. Berlin, New York: 271-278. 
Neumann G. 1961. Untersuchungen zum Weiterleben hethitischen und luwischen Sprachgutes in hellenistischer und römischer Zeit. Wiesbaden.

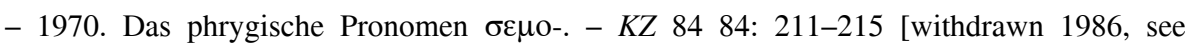
Heubeck 1987: 70].

- 1971. Spätphrygisch $\alpha \kappa \kappa \alpha \lambda \mathrm{\varsigma}$ und $\alpha \kappa \alpha \lambda \alpha$. - Schmitt-Brandt R. (ed.) Donum indogermanicum. Festgabe für Anton Scherer zum 70. Geburtstag. Heidelberg: 155-160.

- 1972. Phryger I. Geschichte, II. Sprache. - Der kleine Pauly 4: 822-824; 824-825.

- 1980. Kleinasien. - Neumann G., Untermann J. (ed.) Die Sprachen im Römischen Reich der Kaiserzeit, [Beihefte der Bonner Jahrbücher 40]. Cologne, Bonn: 167-185. [OPhr. 170f., NPhr. 174f., both 175f.].

- 1981. Die altphrygische Inschrift von Firanlar Köyü. - Kadmos 25. 2: 143-149.

- 1986. Zur Syntax der neuphrygischen Inschrift Nr. 31. - Kadmos 25: 79-84.

- 1987. Rev. of Diakonoff / Neroznak 1985. - Kratylos 32: 88-93.

- 1988. Phrygisch und Griechisch [Sitzungsberichte der Österreichischen Akademie der Wissenschaften, Philosophisch-historische Klasse, 499]. Vienna.

- 1994. Ausgewählte kleine Schriften. Göttingen.

- 1995. Zu phrygischen Namen. - Ofitsch M., Zinko Ch. (eds.) Studia onomastica et indogermanica, Fs Fritz Lochner von Hüttenbach zum 65. Geburtstag, Graz: 129-136.

- 1997. Die zwei Inschriften auf der Stele von Vezirhan. - Gusmani R. et al. (eds.): 13-32.

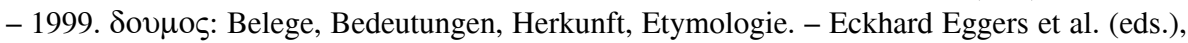
Florilegium linguisticum, Fs Wolfgang P. Schmid zum 70. Geburtstag. Frankfurt a.M.: 345-353.

- 2002. Ein neuer Beleg für $\triangle \mathrm{OYMO \Sigma}$. $H S$ 115: 57-58.

- 2005. Phrygien, Phryger. A: Sprache. - Reallexikon der Assyriologie und Vorderasiatische Archäologie, 10, fasc. 7-8. Berlin, New York: 543-546.

Neumann G., Strobel K. 2005. Phrygien, Phryger. B: Geschichte und Religion. - Reallexikon der Assyriologie und Vorderasiatische Archäologie, 10, fasc. 7-8. Berlin, New York: 546-549.

Orel V. 1990-1991. Position of Phrygian. - Linguistic Association of Canada and the United States 17: 418-426.

- 1993. The position of Phrygian. - Annual of Armenian linguistics 14: 55-67. [essentially a repeat of 1990-1991].

- 1994. Two dialects in New Phrygian? - Kadmos 33: 60-64.

- 1995. An Old Phrygian clay tablet from Persepolis. - Kovets Freundlich-Amit: 128-132.

- 1996. The West Phrygian inscription from Ikiztepe. - Kadmos 35.1: 53-54.

- 1997a. The language of Phrygians. Delmar (New York).

- 1997b. The vocabulary of Phrygian. - Orpheus 7: 37-77 [reproduces 1997a: 408-473 plus somewhat different bibliography].

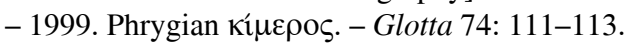

- 2005. Graeco-phrygische Kontaktzonen. - Meiser G. et al. (eds.): 483-494.

Panagl O. 1982. Phrygisch: die Erschliessung einer verschollenen Sprache. - Jahrbuch der Universität Salzburg 1979-1981: 119-123.

Panagl O., Kowal B. 1983. Zur etymologischen Darstellung von Restsprachen: am Beispiel des Phrygischen. - Bammesberger A. (ed.) Das etymologische Wörterbuch: Fragen der Konzeption und Gestaltung. Regensburg: 185-199.

Perpillou J.L. 1986. Le paléo-phrygien, dans son obscure vérité. - RPh 60/2: 275-278.

Perrot G., Chipiez Ch. 1890. Histoire de l'art dans la antiquité, 5. Paris.

Pinault G.-J. 1995. Le problème du préverbe en indo-européen. - Les préverbes dans les langues d'Europe. A. Rousseau (ed.). Paris: 35-39.

Pisani V. 1933. Studii sulla preistoria delle lingue i.-e. [Mem. d. Acad. Lincei]. Rome.

- 1982. Un genitivo singulare frigio? - Kadmos 21.2: 170. 
Polomé E.C. 1986. A note on Thraco-Phrygian numerals: Alan S.C. Ross in memoriam. - JIES 14: 185-189. [entirely contained in the following:]

- 1992. Thraco-Phrygian. - Gvozdanovič J. (ed.). Indo-European numerals. Berlin: 361-367.

- 1996. Beer, runes and magic. - JIES 24.1-2: 99-105.

Popko M. 1972. Stan badań nad językiem frygijskim. - PO I: 59-63.

- 1995. Religions of Asia Minor. Warszawa.

- 1999. Ludy i języki starożytnej Anatolii. Warszawa.

Ramsay W.M. 1882. Studies in Asia Minor. - JHS 3: 1-68.

- 1883. On the early historical relations between Phrygia and Cappadocia. - Journal of the Royal Asiatic Society of Great Britain and Ireland 15: 100-135.

- 1884. Sepulchral customs in ancient Phrygia. - JHS 5: 241-262.

- 1887. Phrygian inscriptions of the Roman period. - KZ 28: 381-400.

- 1888-1889. A study of Phrygian art. - JHS 9: 350-382; 10: 147-189.

- 1889. Phrygian notes. - Beiträge zur Kunde der indogermanischen Sprachen 14: 308-312.

- 1905. Neo-Phrygian inscriptions. - Jahreshefte des Österreichischen Archäologischen Instituts 8: 79-120.

- 1906. Studies in the history and the art of the eastern provinces of the Roman Empire. London.

von Reber F. 1897. Die phrygischen Felsendenkmäler. - Abhandlungen der Historischen Klasse der königlichen bayerischen Akademie der Wissenschaften 21: 529-598 + plates $1-12$.

Roller L.E. 1989. The art of writing at Gordion. - Expedition [Bulletin of the University Museum (Philadelphia)] 31.1: 54-61.

- 1999. In search of God the Mother: the cult of Anatolian Cybele. Berkeley, Los Angeles, London.

Rott H. 1908. Kleinasiatischer Sprachdenkmäler aus Pisidien, Pamphylien, Kappadokien und Lykien. Leipzig [= vols. 5-6 of Ficker (ed.) Studien über christliche Denkmäler].

Ruge W. 1897. Bithynia: Topographie. - Pauly-Wissowa Real-encyclopädie der classischen Altertumswissenschaft, III. 1 Stuttgart:. 507-510.

- 1912. Gordion. - Pauly-Wissowa Real-encyclopädie der classischen Altertumswissenschaft, VII. 2 Stuttgart: 1590.

- 1932. Midaion. - Pauly-Wissowa Real-encyclopädie der classischen Altertumswissenschaft, XV. 2 Stuttgart.: $1524-1526$.

- 1941. Phrygia: Topographie. - Pauly-Wissowa Real-encyclopädie der classischen Altertumswissenschaft, XX. 1 Stuttgart: 781-868.

- 1948. Tyana. - Pauly-Wissowa Real-encyclopädie der Classischen Altertumswissenschaft. VII A-2 Stuttgart: 1630-1642.

Şahin C. 1986. Studien über die Probleme der historischen Geographie des nordwestlichen Kleinasiens. - EpAnatol 7: 125-152.

Sams G. 1994. The Gordion excavations: Final Reports IV: The early Phrygian pottery. Philadelphia.

Saussure F. de 1898. [see reprint in 1922], Récueil des publications scientifiques. Geneva: 542-575 [orig. publ. in Chantre 1898: 165ff.].

Sayce A.H. 1926. The new Neo-Phrygian inscriptions. - JHS 46: 29-35.

Schmid W.P. 1993. Spätphrygische Kleinigkeiten. - Heidermanns F., Rix H., Seebold E. (eds.) Sprachen und Schriften des antike Mittelmeerraums: Fs Jürgen Untermann zum 65. Geburtstag. [Innsbrucker Beiträge zur Sprachwissenschaft 78]. Innsbruck: 377-383.

Schmidt M. 1869. Neue lykische Studien.

Schmitt R. 1963. Der angebliche Phrygergott Bagaios. - Sprache 9: 38-47.

- 1973. Iranisches Sprachgut auf phrygischen Inschriften? Eine kritische Überprüfung. - Sprache 19: 44-58. 
- 1982. Iranische Namen in den indogermanischen Sprachen Kleinasiens (Lykisch, Lydisch, Phrygisch). - Mayrhofer M., Schmitt R. (eds.) Iranisches Personennamenbuch. [vol. V-4]. Vienna.

- 1983a. Sprachverhältnisse einheimischer Sprachen in den östlichen Provinzen. - ANRW II 29.2: 565-568.

- 1983b. Die Sprachverhältnisse in den östlichen Provinzen des Römischen Reiches. - Haase W. (ed.) Aufstieg und Niedergang der Römischen Welt II. Berlin: [vol. 2, part 2]: 554 $-586$.

Širokov O.S. 1989. Genetičeskie svjazi frigijskogo jazyka. - LBalk 32/3-4. 165-168.

Solmsen F. 1897a. Zum Phrygischen. - KZ 34: 36-68.

- 1897b. Thrakisch-Phrygisches. - KZ 34: 68-80.

Sowa W. 2006. Anmerkungen zum Balkanindogermanischen. - Schweiger G. (ed.) Indogermanica [Fs Gert Klingenschmitt]: 611-628.

- 2007a. A note to "Phrygian" words in Greek. - SEC 12: 153-170.

- 2007b. Anmerkungen zum Verbalsystem des Phrygischen. - IF 112: 69-95.

Specht F. 1939. Sprachliches zur Urheimat der Indogermanen. - KZ 66: 1-74.

Stang Ch.S. 1967. Phrygisch $\alpha \kappa(\kappa) \alpha \lambda \mathrm{\alpha},-\alpha .-N T S$ 21: 127-132.

- 1977. Zum Phrygischen. - NTS 31/1: 17-19.

Steuart J.R. 1842. A description of some ancient monuments with inscriptions still existing in Lydia and Phrygia. London.

Texier Ch. 1839. Description de l'Asie Mineure. 1. Paris.

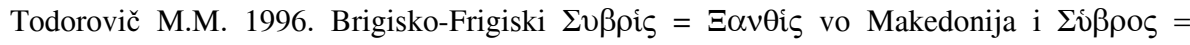

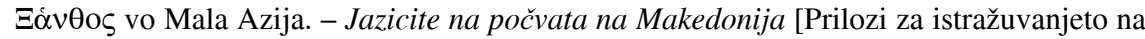
istoriata na kulturata na počvata na Makedonija, Kniga 3]. Skopje.

Torp A. 1894. Zu den phrygischen Inschriften aus römischer Zeit. [Videnskabssetskabets skrifter, II. Hist.-fil. Klasse 2.]. Christiania.

- 1896. - Skrifter udgivne af Videnskabsselkabet i Christiana. [Hist.-filos. Klasse]. Christiania: 3-19.

- 1901. - Beiträge zur Kunde der indogermanischen Sprachen 27: $280 \mathrm{ff}$.

- 1908. Eine altphrygische Inschrift aus Kappadokien. - Mélange Bugge: 210-215.

Treidler H. 1967. Gordion. - Der kleine Pauly II. Munich: 846.

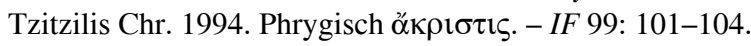

- 1995. Die paläobalkanischen Sprachen im Lichte der neugriechischen Dialekte. - Sprache 37/1: 85-94.

Untermann J. 1980. Trümmersprachen zwischen Grammatik und Geschichte. Opladen.

- 1983. Indogermanische Restsprachen als Gegenstand der Indogermanistik. - Le lingue indoeuropee di frammantaria attestazione [Die indogermanischen Restsprachen: Atti del Convegno della Società Italiana di Glottologia e della Indogermanische Gesellschaft, Udine]. Pisa: 11-28.

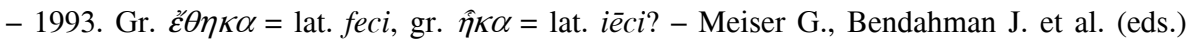
Indogermanica et Italica [Fs Helmut Rix zum 65. Geburtstag, Innsbrucker Beiträge zur Sprachwissenschaft 72]. Innsbruck: 461-468.

Varinlioğlu E. 1985. Eine neue alt-phrygische Inschrift aus Tyana. - EpAnatol 5: 5-7.

- 1991. Deciphering a Phrygian inscription from Tyana. - La Cappadoce Méridional jusq’ à la fin de l'epoque romaine. État les recherches [Actes Colloque Istanbul, avril 1987]. Paris: 29-36.

- 1992. The Phrygian inscriptions from Bayındır. - Kadmos 31.1: 10-20.

Vassileva M. 1997. A few notes on the recent Phrygian epigraphic data. - Gusmani R. et al. (eds.): 267-269.

Walpole R. 1820. Travels in various countries of the East. London.

Weber W. 1908. in Rott: 347-382 (presentation of the Phr. inscriptions). 
Werner R. 1969. Die Phryger und ihre Sprache, Bibliotheca Orientalis 26: 177-182.

West M.L. 2003. Phrygian metre. - Kadmos 42: 77-86.

Witczak K.T. 1992. Some remarks on the New Phrygian inscription No. 88. - LPosn 34: 157 $-162$.

- 1992 / 1993. Two Bithynian deities in the Old and New Phrygian inscriptional texts. - FO 29: 265-271.

Woodhouse R. 2005. Assibilative palatalization of tectals in Phrygian and the adequacy of bitectal frameworks for Proto-Indo-European. - IF 110: 205-234.

- 2006. Conditioned devoicing of mediae in Phrygian. - SEC 11: 157-191.

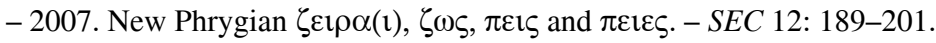

- 2008. Old Phrygian kcianaveyos. - SEC 13: 179-190.

- in press a. Devoicing of PIE mediae in Phrygian. - HS.

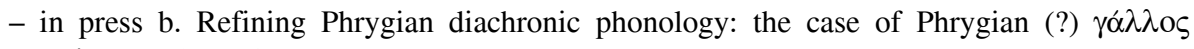
'priest'. - SEC 14.

Woudhuizen F.C. 1993. Old Phrygian: some texts and relations. - JIES 21: 1-25.

Young R.S. 1951. - Expedition [Bulletin of the University Museum (Philadelphia)] 16.1: 3-19 .

- 1953a. - Expedition, [Bulletin of the University Museum (Philadelphia)] 17.4: 3-39. [Brixhe, Lejeune 1984: xvii].

- 1953b. Where Alexander the Great cut the Gordian knot: excavations which throw new light on the Phrygians and Hittites of ancient Gordion. - Illustrated London News London $3^{\text {rd }}$ January: 20-23.

- 1955a. A city two thousand years old when Alexander the Great entered it: Gordion revealed in its Phrygian and Persian phases. - Illustrated London News $17^{\text {th }}$ September: 478 480.

- 1955b. Gordion: preliminary report, 1953. - AmJArchaeology 59: 1-18.

- 1958. The Gordion campaign of 1957: preliminary report. - AmJArchaeology 62: 139-154.

- 1963. - Proceedings of the American Philosophical Society 107: 348-364.

- 1964. The 1963 campaign at Gordion. - AmJArchaeology 68: 279-292.

- 1966. The Gordion campaign of 1965. - AmJArchaeology 70: 267-278.

- 1968a. The Gordion campaign of 1967. - AmJArchaeology 72: 231-241.

- 1968b. Gordion: a guide to the excavations and museum. Ankara. [French transl. J. Karoche, Ankara 1975).

- 1969. Old Phrygian inscriptions from Gordion: towards a history of the Phrygian alphabet. - Hesperia 38/2: 252-296.

Zgusta L. 1964. Kleinasiatische Personennamen. Prague.

- 1982. Weiteres zum Namen der Kybele. - Sprache 28: 171-172.

- 1984. Kleinasiatische Ortsnamen. Heidelberg.

Ziegler. K. 1969. Midaion. - Der kleine Pauly III. Munich: 1287. 